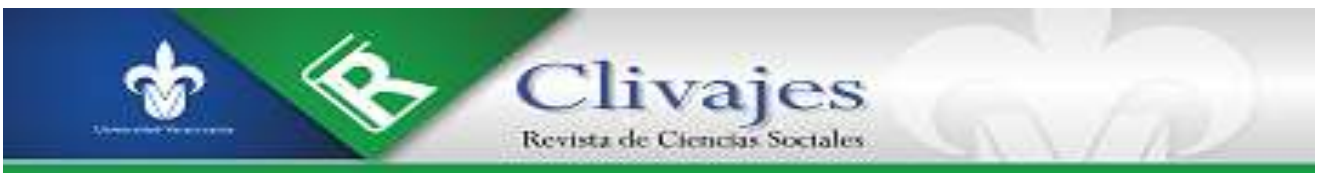

Gualberto Díaz González y Susana Córdova Santamaría FOTOGRAFíA Y ACTORES DEL CAMPO CAFETALERO DE LA REGIÓN CENTRO DE VERACRUZ, MÉXICO: MUJERES, NIÑOS Y JÓVENES (2011-2012)

Clivajes. Revista de Ciencias Sociales. Año VI, número 12, julio-diciembre 2019, pp. 88-107.

http://clivajes.uv.mx/index.php/Clivajes/editor/proofGalley/2581/4450 Instituto de Investigaciones Histórico-Sociales, Universidad Veracruzana

Recibido: 03/06/2019

Aceptado: $15 / 07 / 2019$

Dictaminado: 20/II/19

Publicado: 15/11/2019 


\title{
FOTOGRAFÍA Y ACTORES DEL CAMPO CAFETALERO DE LA REGIÓN CENTRO DE VERACRUZ, MÉXICO: MUJERES, NIÑOS Y JÓVENES (2011-2012)
}

\author{
Gualberto Díaz González ${ }^{1}$ \\ Susana Córdova Santamaría ${ }^{2}$
}

\section{Resumen}

La historia del café en Veracruz ha forjado toda una cultura en los habitantes de la Faja de Oro. Generaciones de familias cafeticultoras y jornaleras sostienen el cultivo que llegó a México a finales del siglo XVIII. El equipo de Cultura del proyecto Café In Red, del Fondo Institucional de Fomento Regional para el Desarrollo Científico, Tecnológico y de Innovación (fordecyt), se propuso conocer y compartir la vida de estas familias para que, a través de la vista, la voz y el oído, además de los aromas y sabores que vuelcan las pasiones del café, conozcamos los actuales rostros de la cafeticultura.

Las políticas sociales difícilmente incorporan al arte en la socialización del conocimiento, y para Café in Red ha sido un reto integrar la cultura en el proyecto del Fondo Institucional del fordecyt. Pretendemos integrar arte e investigación social en el trabajo comunitario con una mirada crítica hacia nosotros mismos y frente a los demás, observado los rostros de los cafetaleros, mujeres y niños atentos a una representación teatral, mirando las fotografías expuestas en las paredes de un salón social o leyendo las fichas que complementan la información. Es una forma de transmitir conocimiento y alimentarnos de los saberes locales, a contrapelo de la transmisión vertical del saber y desde la construcción de un archivo de historia oral.

Palabras clave: Cultura cafetalera, Fotografía, Historia oral, Veracruz

\section{INTRODUCCIÓN}

En el presente texto se exponen resultados preliminares del proyecto coordinado por el Equipo de Cultura del Fondo Institucional de Fomento Regional para el Desarrollo Científico, Tecnológico y de Innovación (FORDECYT), luego de dos años de trabajo de campo en comunidades cafetaleras de la región Centro de Veracruz, México. El proyecto fue aprobado por el comité técnico y de administración del FORDECYT, CONACYT, con número 139378. La propuesta fue desarrollada por el Instituto de

\footnotetext{
${ }^{1}$ Sociólogo, con estudios de maestría en Literatura Mexicana (IIL-L, UV) y doctorado en Historia y Estudios Regionales (IIH-S, UV), es profesor-investigador de la Facultad de Sociología. Se ha especializado en el uso de medios audiovisuales para la investigación social. De sus trabajos destacan los foto-ensayos: Otro mundo es posible, imágenes del zapatismo (1994-2007), Cortadores de caña (2000), La Habana, rostros de la revolución (2003), y los documentales: Los agraviados (2007), Kalli Luz Marina (2009), Sierra de Zongolica, voces sobre el agua (2011) y Vidas del café (2012); es coeditor (2009) del libro Sociología, educación y nuevas tecnologías. Xalapa: UV.

${ }^{2}$ Socióloga con estudios de maestría y doctorado en Historia, es profesora-investigadora del Centro Regional Universitario Oriente (CRUO) de la Universidad Autónoma de Chapingo, ubicado en Huatusco, Veracruz. A partir de 1995, ha realizado trabajos de investigación sobre la historia del café.
} 
Ecología A.C., el Centro Regional Universitario Oriente de la Universidad Autónoma de Chapingo, la Universidad Veracruzana y la Asociación Civil Sotavento, Creación Interdisciplinaria, entre otras instituciones, siendo, por lo tanto, un proyecto interinstitucional y transdisciplinario.

Para abordar la temática se formaron cinco equipos de trabajo, por cada uno de los grandes objetivos: a) sistema de inteligencia, b) servicios ambientales, c) producción agroforestal, d) comercialización y regionalización de la producción, y d) desarrollo empresarial. Particularmente, en el equipo de desarrollo empresarial, se planteó un trabajo específico para investigar, impulsar, recrear y difundir la cultura cafetalera. El Equipo de Cultura se dio a la tarea de investigar, estudiar y difundir la cultura cafetalera veracruzana en una región específica, como se registra a continuación, a partir de una necesidad del sector para integrar a un amplio número de jóvenes a los que cada día les resulta difícil participar en la economía de su lugar de origen y los cuales son expulsados a otros lugares del país o incluso fuera de él.

La Faja de Oro de Café es una región que comprende los municipios de Altotonga, Atzalan, Misantla, Tenochtitlan, Juchique de Ferrer, Yecuatla, Alto Lucero, Naolinco, Jilotepec, Xalapa, Coatepec, Xico, Teocelo, Emiliano Zapata, Cosautlán de Carvajal, Tlaltetela, Totutla, Sochitepec, Tlacotepec, Huatusco, Tomatlán, Naranjal, Córdoba, Zongolica, Veracruz: Chichiquila, Quimixtlán, Chilchotla, Puebla.

De acuerdo con el paradigma de sustentabilidad en la agricultura, nuestra investigación se desarrolló con métodos cualitativos e historia oral. Esta última se caracteriza por convertir en fuente documental o videograbada el testimonio de actores sociales e informa, desde su perspectiva, sobre el acontecer histórico. A partir de una grabación, el entrevistado informa sobre la historia social que ha vivido.

Con base en estas metodologías, se aborda un tema poco estudiado en la dinámica cafetalera para esclarecer una problemática del momento histórico en el que estamos inmersos: la crisis ambiental y la necesidad de desarrollar una propuesta de agricultura sustentable.

La observación participante, las preguntas iniciales, el trabajo cotidiano con quienes tienen hoy la necesidad inmediata de construir no solamente su futuro sino su identidad en la región cafetalera: niños, jóvenes y mujeres. Por regla general, la problemática cafetalera se reduce a los precios y łas acciones que desarrollan los dueños de los predios para producir y vender, en busca de la calidad que impone el mercado. Pero los integrantes de las familias representan también la unidad de la economía cafetalera; por ello es necesario conocerlos, al igual que al sector más débil: los 
jornaleros migrantes que viajan en época de cosecha para vivir temporalmente del corte de café.

Imágenes fotográficas y recuperación de la historia del café, mediante la oralidad, concentran el resultado de esta investigación, a partir de talleres y exposiciones fotográficas con los productores y sus familias en las comunidades.

\section{Cultura Cafetalera en la Faja de Oro}

Si partimos de que nuestra investigación se enmarca en el universo cafetalero del centro de Veracruz, debemos explicar cómo se ha construido la cultura cafetalera durante el siglo XXI. En primer lugar, señalamos que el momento histórico en el que se sitúa la llegada del "grano de oro" es la Revolución Industrial, cuando el desarrollo capitalista conquista el orbe, ofertando mercancías a los ávidos consumidores cuyo número crecía en las metrópolis.

El café era, sin duda, una de las tantas mercancías que conquistaría tierras poco transformadas durante la colonización en México y América Latina. Considerando que su hábitat natural se ubicó en la franja intertropical, al cultivarse en esas nuevas tierras, su impacto económico integraba a nuevas regiones del naciente Estado mexicano al mercado internacional y, al mismo tiempo, transformaba la vida social y política de los actores de la cultura cafetalera. Este proceso inició en la segunda mitad del siglo XVIII y tuvo un auge importante durante el Porfiriato, es decir, a finales del siglo XIX.

El ingreso del aromático fue un proceso lento, no solamente por la adaptación de la semilla a las tierras aptas para su crecimiento y producción, sino también en su integración a la sociedad que lo consumía y a la población que lo cultivaba.

Cuando el café se comenzó a cultivar comercialmente, una de las tres rutas de ingreso al país fue el Puerto de Veracruz; fue ahí adonde llegó por vez primera y desde ahí se le conoció en México. Quienes lo trajeron fueron los modernos hacendados que durante el régimen de Porfirio Díaz (1876-1911) establecieron fincas cafetaleras, respondiendo así a la creciente demanda internacional del grano.

Los hacendados invirtieron sus capitales en la cafeticultura; desde el traslado de las plántulas de café hasta el aprendizaje y adaptación del grano a las tierras; desde la integración del cultivo con otras producciones de la hacienda - como la caña- y la cría de ganado, hasta la construcción del beneficio y la compra y el traslado de la maquinaria provenientes del oriente de Estados Unidos o Inglaterra. Es decir, sólo con la 
tecnología apropiada pudo introducir el cultivo del café este sector social ávido de enriquecerse.

Si bien los propietarios iban adquiriendo práctica, conocimientos y experiencias en la toma de decisiones de la plantación y el beneficiado del grano para ofertarlo en el mercado internacional, sus trabajadores iban adquiriendo, al mismo tiempo, el conocimiento sobre los requerimientos de la planta para producir en las tierras del país sin limitaciones técnicas. Es un hecho que ambos sectores sociales fueron los pilares de la cafeticultura mexicana del siglo Xx y finalmente los constructores de la cultura cafetalera que hoy presentamos en imágenes.

Del sector de ex trabajadores de las haciendas emergieron los primeros ejidatarios cafetaleros, quienes a partir de la Revolución mexicana y a raíz de su lucha por tierras productoras de café, iniciaron el reparto agrario en el centro del Estado veracruzano, donde se cultivarían cafetos durante la segunda mitad del siglo Xx, lo cual implicó una transformación en su habitual forma de cultivar, en su parcela. Para entonces, debieron integrar plantas para su manutención diaria o para venderlas entre su cafetal -Por estas causas consideramos necesario internarnos en el mundo cotidiano que ahora los representa y testimoniar con imágenes el presente.

A través de un taller de Historia Oral, convocamos a cafetaleros para que recapitularan sobre sí mismos y valoraran qué tanto conocían acerca del cultivo, de sus tierras y de la bebida. El interés por recuperar la historia en las comunidades cafetaleras veracruzanas se fijó con adultos mayores y jóvenes de tal forma que, a través de varias sesiones del taller, los participantes hablaban de sus intereses, planteaban problemas o se hacían preguntas para posteriormente emprender sus propias búsquedas con familiares o señores y señoras de mayor edad en el lugar; después de este trabajo, organizaban su información para presentar conclusiones en una sesión final.

El resultado ha sido una experiencia que interesa y motiva a hombres y mujeres participantes a saber más sobre los temas que ellos mismos no conocen sobre el pasado de sus comunidades, a comprender los símbolos de la comunidad o región y a tener mayor claridad acerca de su identidad en tanto actores sociales que tienen y han cumplido un rol familiar, económico, social, político, y, sobre todo, histórico.

El taller ha sido un recuento de la historia de los participantes en lo que hoy muchos consideran hechos tradicionales de la comunidad y los propios protagonistas voltean a ver su pasado, es decir, se ven como actores de un proceso histórico que explica lo que son actualmente. 
Estudiar la cultura cafetalera implica, primero, señalar el significado de la cultura en términos generales, para después pensar en las particularidades de un cafetalero. La cultura, en su sentido más amplio, puede considerarse como el conjunto de los rasgos distintivos, espirituales y materiales, intelectuales y afectivos que caracterizan a una sociedad o un grupo social. Ésta abarca, además de las artes y las letras, los modos de vida, los derechos fundamentales del ser humano, los sistemas de valores, las tradiciones y las creencias. ${ }^{3}$

Por lo anterior, las fotografías que presentamos expresan la cultura cafetalera: no solamente reflejan el conocimiento que tienen los cafetaleros para producir, beneficiar y comercializar el café, sino también la forma de enfrentar la vida cotidiana a través de sus costumbres y tradiciones, así como las decisiones que toman para resolver nuevos retos en la encrucijada del siglo XXI.

\section{FOTOGRAFÍA E INVESTIGACIÓN SOCIAL}

Rito social, práctica de consumo o herramienta de trabajo, al asignarles cada cual una función social, las imágenes fotográficas proporcionan material para la sociología, ciencia que ha mantenido una doble relación con la fotografía: la estudia como producto cultural o la utiliza como herramienta para sus investigaciones; sin embargo, ha prevalecido más el uso de la fotografía como recurso complementario para la investigación, que como base para el análisis crítico y creativo (Díaz, 2009).

Ciertamente, las fotografías reflejan aspectos de lo real y proponen una manera de mirar. Al evocar el pasado, las imágenes nos conectan con la cotidianidad y con la memoria colectiva. La sociología usa la cámara para “anotar” situaciones, objetos, relaciones, espacios, procesos..., aspectos que la palabra escrita no alcanza a nombrar. La fotografía es un rito social y una forma de dar valor al otro, apostando, desde la ética, a construir un puente de ida y vuelta: "Yo fotografío porque eres importante para mí, porque lo que haces y lo que dices me interesa y, además, esta fotografía puedo devolvértela porque sé que a ti también te va a gustar". Como forma de interacción social en el trabajo de campo, la fotografía suscita el encuentro con el otro.

Desde 1824 la imagen fotográfica llegó para "democratizar todas las experiencia convirtiéndolas en imágenes” que constituyen y designan al mundo moderno. También,

\footnotetext{
${ }^{3}$ Françoise Rivière (octubre de 2009). UNESCO. Recuperado de: http://unesdoc.unesco.org/images/0018/001876/187629s.pdf
} 
desde su nacimiento, la práctica de la fotografía ha combinado arte y verdad, creación y documento, porque cualquier fotografía cumple una función social, no sólo estética, "el registro de la cámara incrimina" (Sontag, 1977, p. 45).

El equipo de Cultura del proyecto FORDECYT, Café in Red, se propuso capturar imágenes de la vida cotidiana de familias cafetaleras de Veracruz, senderos y paisajes, manos y máquinas, miradas y sonrisas de quienes forman actualmente la cultura cafetalera en la región: Rostros del café: cultura y modo de vida en la Faja de Oro de Café". Dado que las políticas sociales difícilmente incorporan el arte en la socialización del conocimiento, fue un reto para Café in Red integrar la cultura visual en el proyecto FORDECYT, y aún más integrar arte e investigación social en el trabajo comunitario, donde el quehacer artístico deja de considerarse "superfluo" para convertirse en una mirada crítica de uno mismo y de los demás, observando los rostros de los productores cafetaleros y sus familias, mujeres y niños, atentos a una representación teatral, mirando las fotografías expuestas en las paredes de un salón social o leyendo las fichas que complementan la información de las imágenes. Escuchar sus preguntas es otra forma de transmitir conocimiento y alimentarse de los saberes locales y comunitarios, pues la transmisión de conocimiento pasa también por una forma no burocratizada, sino creativa y crítica, a contrapelo de la transmisión vertical del saber.

Fotografiar vuelve consciente la observación y el concepto visual que se dispone ante la vista. Quien observa una fotografía, la interpreta según los conocimientos que tenga de lo fotografiado y sobre quién fotografió. Entonces ¿qué es lo que da sentido a una fotografía? La elección de lo que se captura o la interpretación de lo capturado. Quien observa, ¿cuenta con los códigos y las referencias para interpretar lo que ve? Elegir capturar una imagen no depende de fotografiar $x$ o $y$, sino de fotografiar en el momento $x$ o en el momento $y$; en qué situación y en qué circunstancia se registra. (Berger, 1978, p. 33). En este trabajo, el registro fotográfico se centró en capturar imágenes de los jornaleros en plena faena de corté de café y después de su jornada laboral, en la interacción.

La imagen siempre ha necesitado de un título, una fecha, una firma, un pie de foto para su lectura. ¿Cómo puede significar una fotografía sin el referente de la escritura? Será preciso buscar otras posibilidades de relación entre fotografía y literatura, donde texto e imagen dialoguen para juntos ofrecer "otra manera de contar", como diría John Berger (1978).

La selección y edición de las imágenes puede hacerse a la manera de los fotoensayos de Nacho López, quien desde los años cincuenta del siglo pasado publicaba 
en revistas como Hoy y Siempre! López es considerado uno de los padres del fotoperiodismo mexicano, pues influyó en toda una generación de fotógrafos con el compromiso de hacer fotografía social. López llamó a reivindicar el oficio del fotógrafo, porque "la función fundamental de la fotografía es explicar la realidad" (1996, p. 3).

Como sabemos, con la invención de la fotografía surge la posibilidad de documentar una realidad o inventarla (González, 2005, p. 164). Del “esto ha sido” al "esto ha sido porque yo lo he inventado", el fotoensayista Nacho López apuesta por la segunda opción, siendo deudor de fotógrafos de finales del siglo XIX y principios del $\mathrm{XX}$, como Emilio Lange y los hermanos Torres, quienes también publicaron secuencias fotográficas narrativas posadas, por lo que puede decirse que Nacho López no inventó el fotoensayo, sino que continuó con una tradición fotográfica en México, que no veía a la fotografía como una réplica de la realidad (2000, p. 67).

A continuación se presenta una selección fotográfica del fotoensayo "Rostros del café, cultura y modo de vida en la Faja de Oro de Café" (2012), realizado durante la investigación.

\section{ROSTROS DEL CAFÉ: NIÑOS, MUJERES Y JÓVENES}

El modo de ver guía lo observado y el registro de la cámara nos conecta con la vida cotidiana y la memoria colectiva, al tiempo que provoca preguntas como ¿qué me vincula con lo que estoy viendo? Aquí se trata de mirar a través de la lente fotográfica el quehacer de un fragmento social poco estudiado en el dinámico sector cafetalero veracruzano. La imagen fotográfica proporciona datos cualitativos aparentemente imperceptibles, pero con significados sociales reveladores. Siendo la transición generacional un punto estratégico en las alternativas de desarrollo sustentable, presentamos retratos y testimonios de niños, jóvenes y mujeres que representan en este momento la cultura cafetalera veracruzana del siglo XXI. 


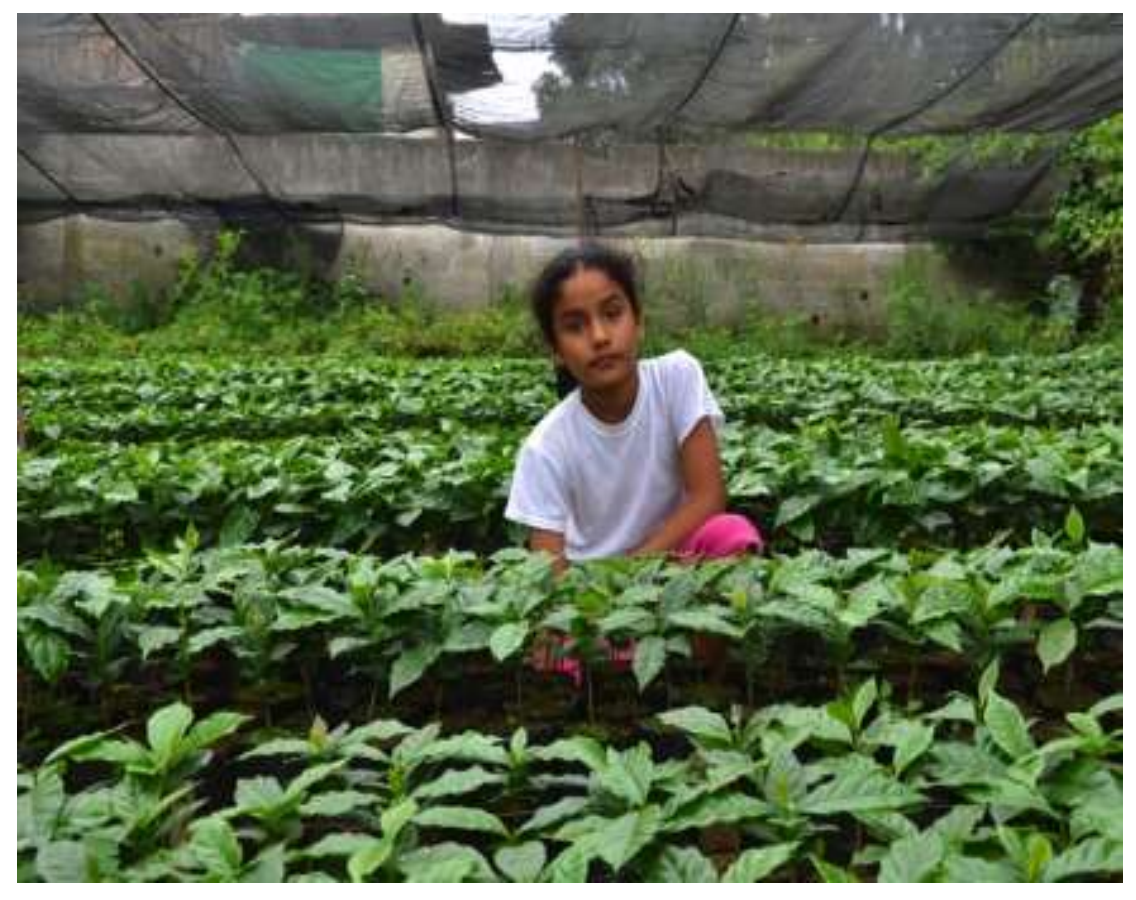

BETY, NIÑA DEL CAFÉ Invernadero de su padre, don Beto, pequeño productor de Mata de indio.

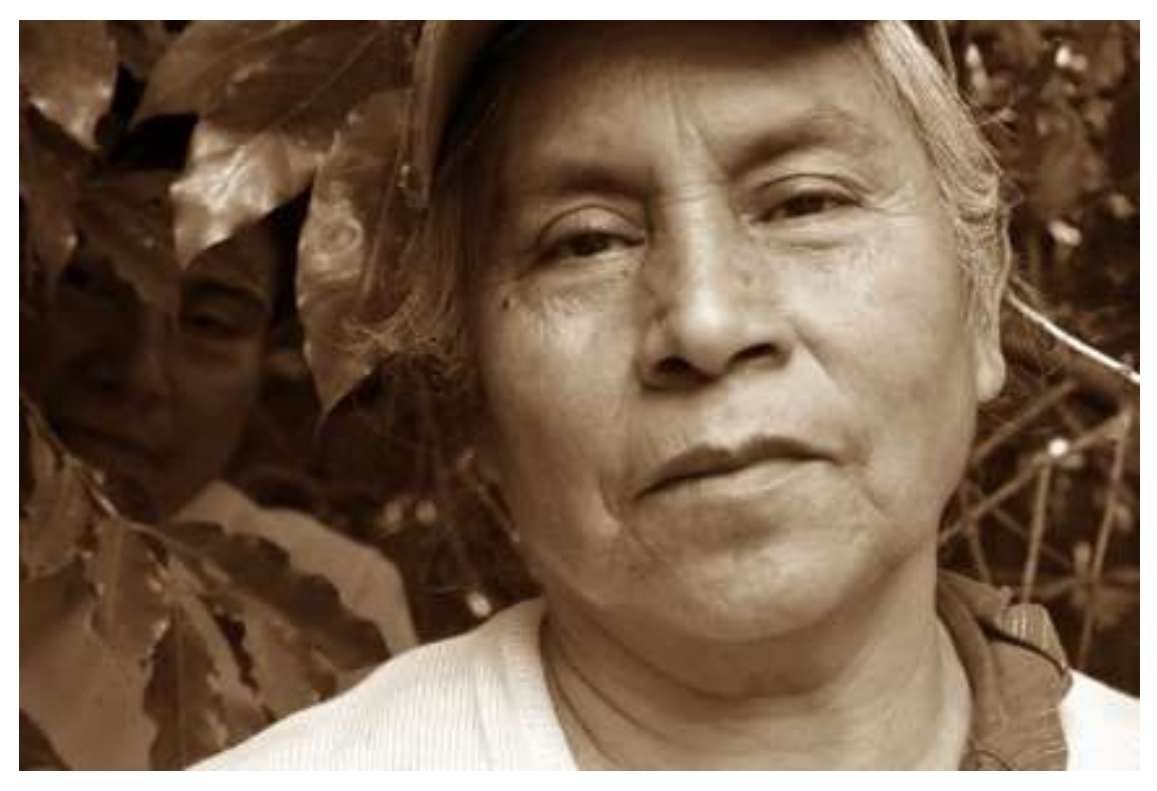

DoÑa TeRE CON SU hiJa CoRTANdo CAFÉ

Finca "El Mirador"

Febrero de 2012 


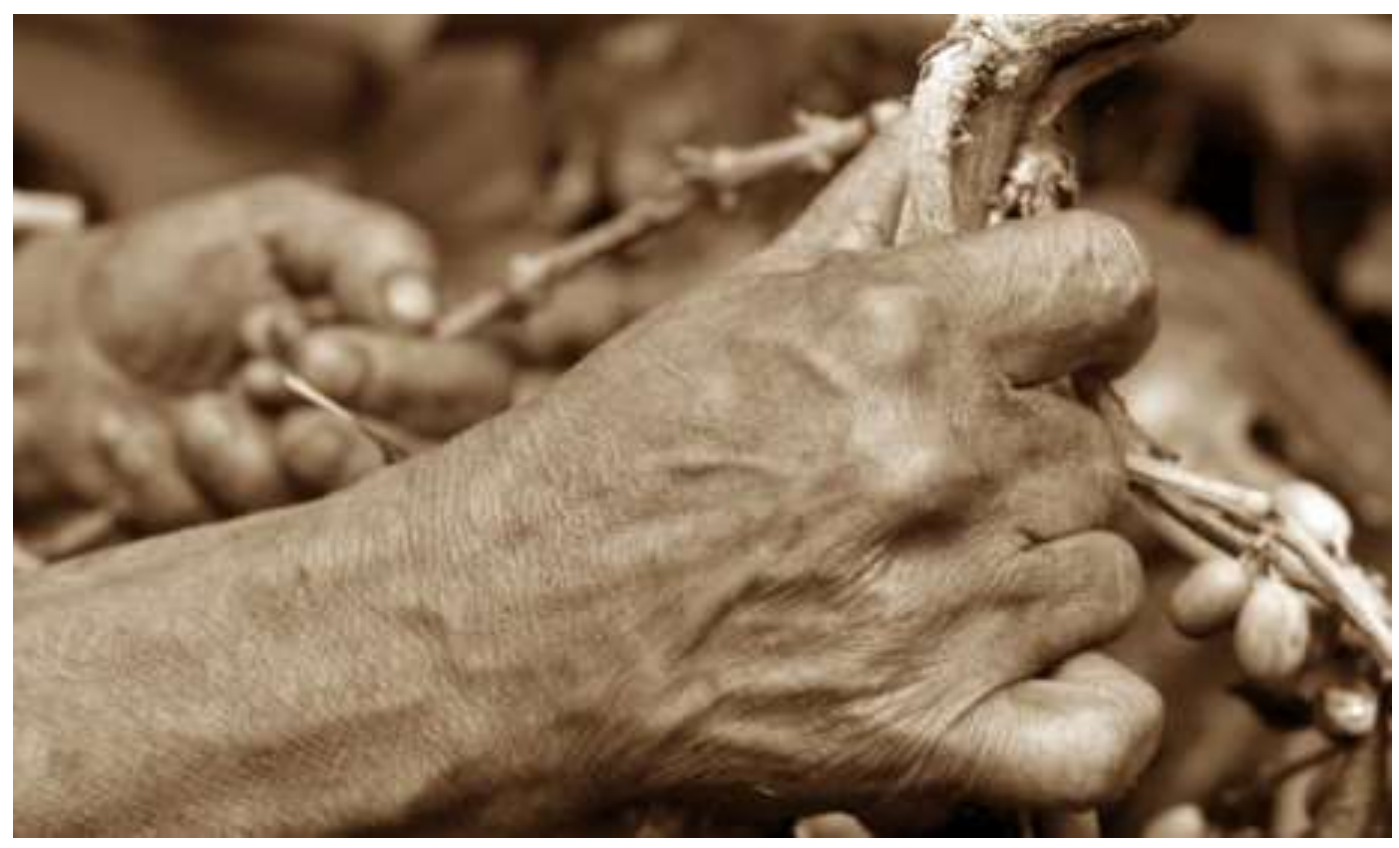

30 AÑOS COSECHANDO CAFÉ

Marzo de 2011

Doña Tere tiene 57 años de edad y sus manos llevan 30 cosechando el grano; padece diabetes y su hija Reina, de 37 años, sufre epilepsia y también corta café. Jornalera de siembre, doña Tere carece de un pedazo de tierra propio para vivir:

Hay que trabajar para mantenerse, para poder sobrevivir, para poder sobrellevarla, porque ya no teniendo esposo no es lo mismo. Soy originaria de Cruz Verde, municipio de Totutla. Tengo 45 viviendo aquí en El Mirador, adonde llegué en busca de trabajo, y también nos dieron casa cuando menos para vivir..., hasta ahorita, porque casa propia no tenemos, ni terrenos. Mientras el ingeniero no diga "se van de aquí", pues aquí estaremos todavía (Teresa Chacón, comunicación personal, 31 de marzo, 2011).

Desde las faldas del Pico de Orizaba o de la Sierra de Zongolica, familias enteras viajan a la región de Huatusco para trabajar temporalmente en el corte de café. Ahí viven, amontonados, en barracas que construyen los cafetaleros que los contratan. Comen frijol, chile y tortillas, a veces carne de pollo o chicharrones, alimentos que no siempre consumen en su lugar de origen. 


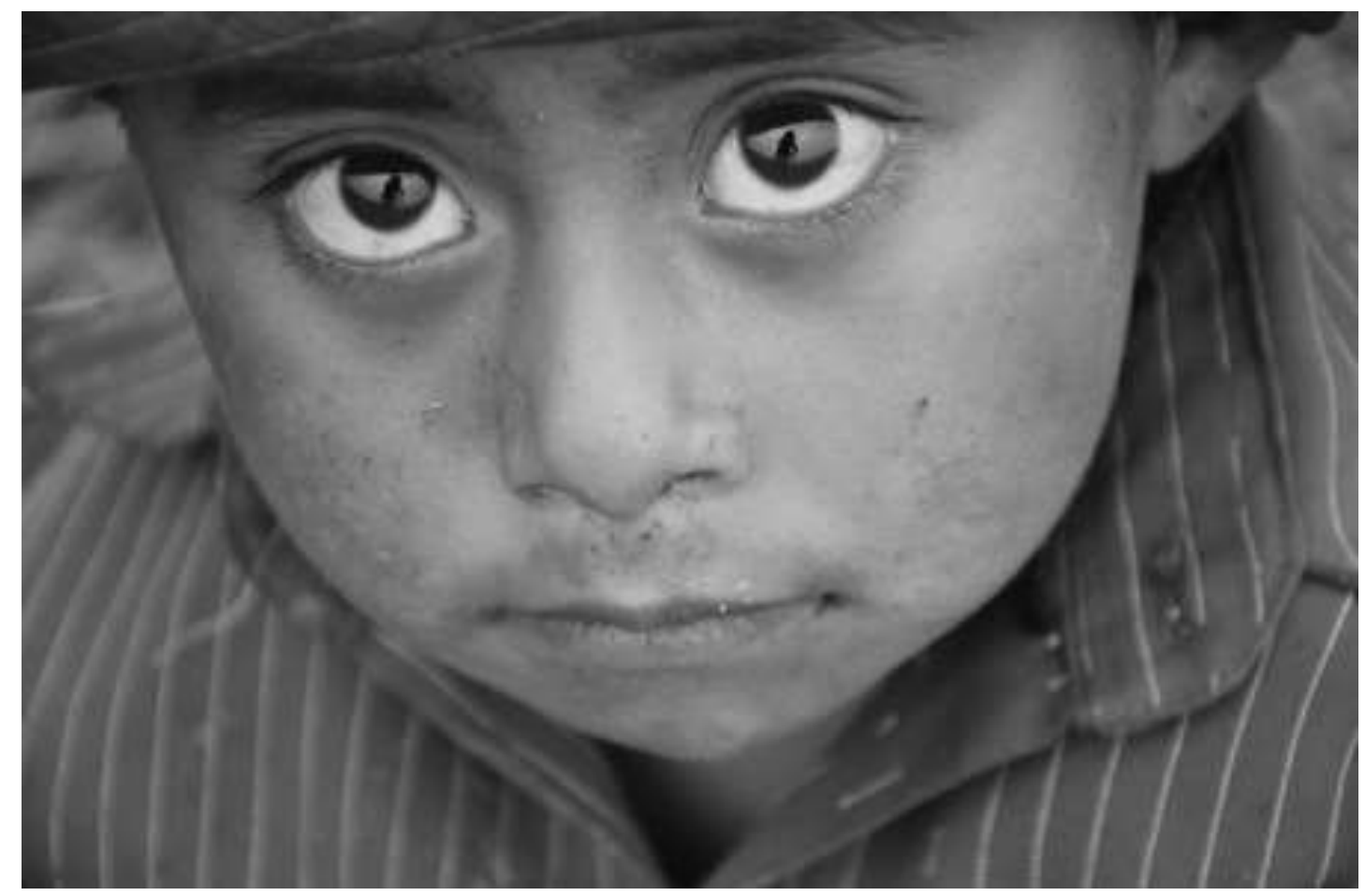

JORNALERO

Los niños que miran sorprendidos a la cámara, también acompañan a sus padres a cosechar el grano y durante el año viajan por temporadas a la pizca del chile o al corte de la flor a Sonora, Sinaloa, entre otros lugares. 


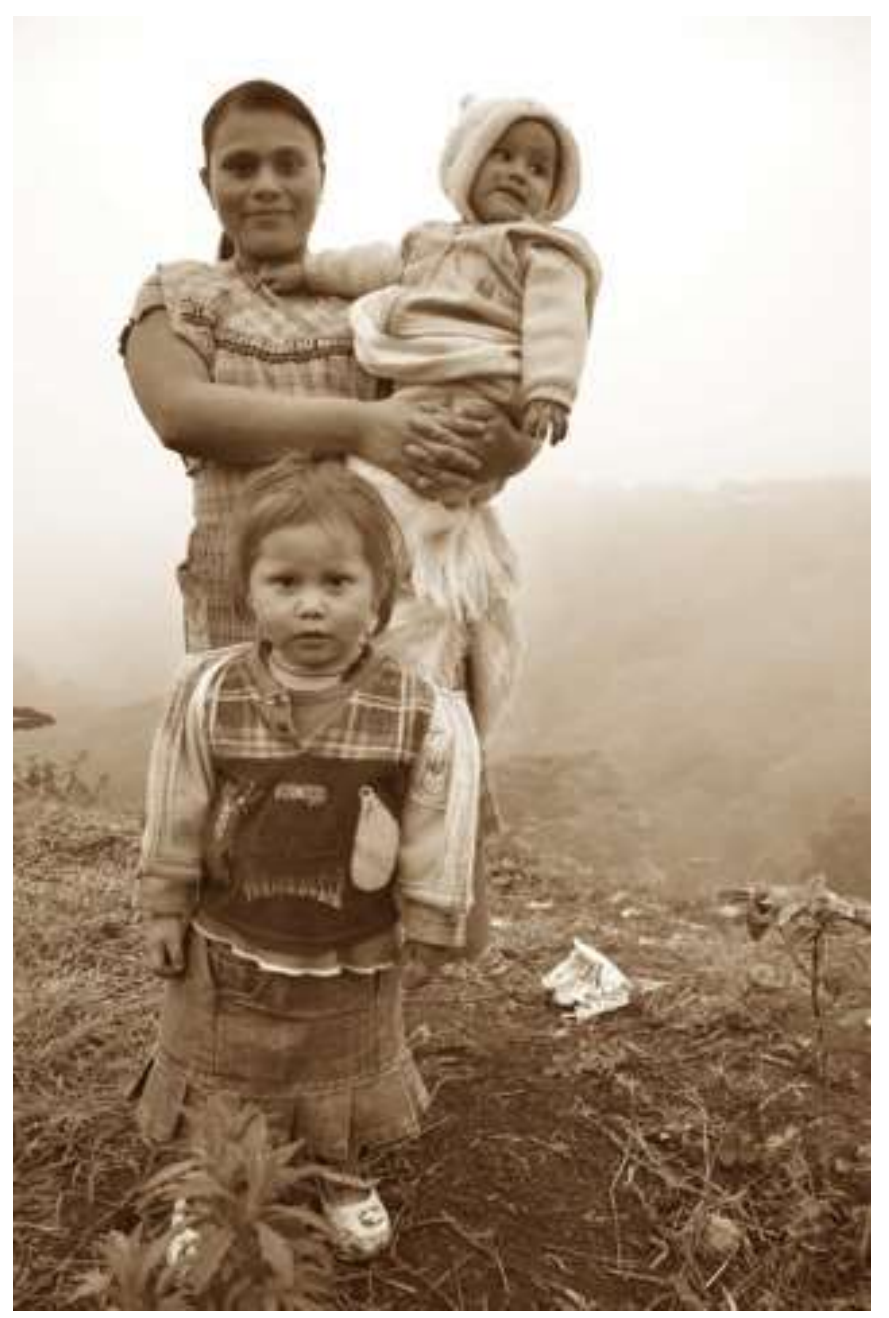

DoÑa Petra GuZmán Y FAMILIA Noviembre de 2012

Doña Petra viene con su familia del municipio La Perla a trabajar en el corte de café de Chilapa. Se levanta a cocinar y hacer el bastimento entre las cuatro y cinco de la mañana. Ella y su familia se van a la cosecha; regresan alrededor de las cinco de la tarde. Entre los cuatro, cortan en promedio 200 o 250 kilos de café al día. Les pagan dos pesos por kilo en la temporada 2012. Doña Petra compara las tierras frías de las faldas del Pico de Orizaba con las húmedas y productivas de la región de Huatusco:

En estos terrenos que se mantienen fértiles, pensaríamos que si tuviéramos dinero ahora, sí que compraríamos unas dos "hectaritas" para sembrar, pero como somos pobres ¿dónde vamos agarrar dinero?" (Comunicación personal, 25 de noviembre, 2011). 


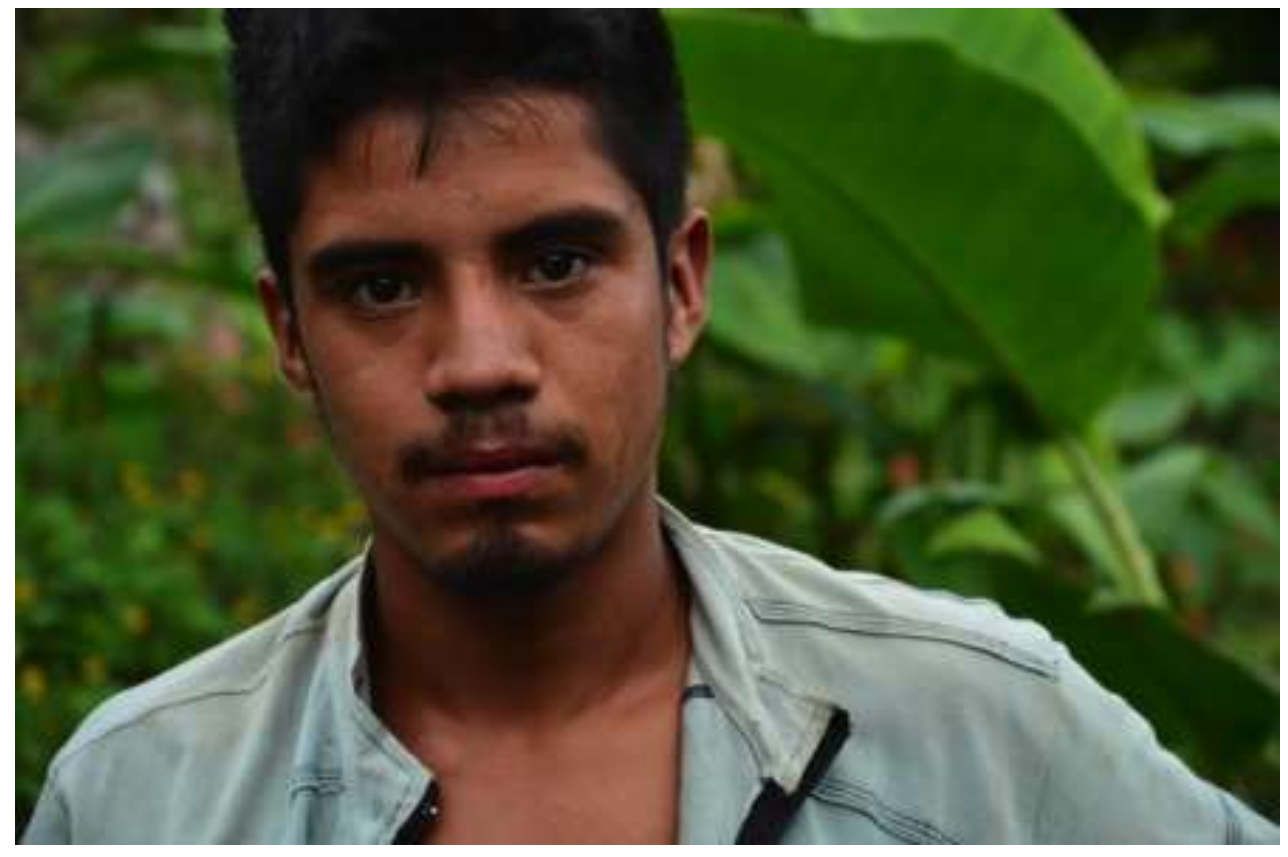

JORNALERO

El Quilate, municipio de Atzalan,

Veracruz.

Noviembre de 2012

Indispensables para la recolección del grano, los cortadores de café han sido parte del flujo migratorio desde que llegó el grano en el siglo XIX. Son parte de una comunidad que busca trabajo en varias regiones de México, incluyendo el norte, aunque prefieren las bondades del clima y el trato que reciben de los cafetaleros.

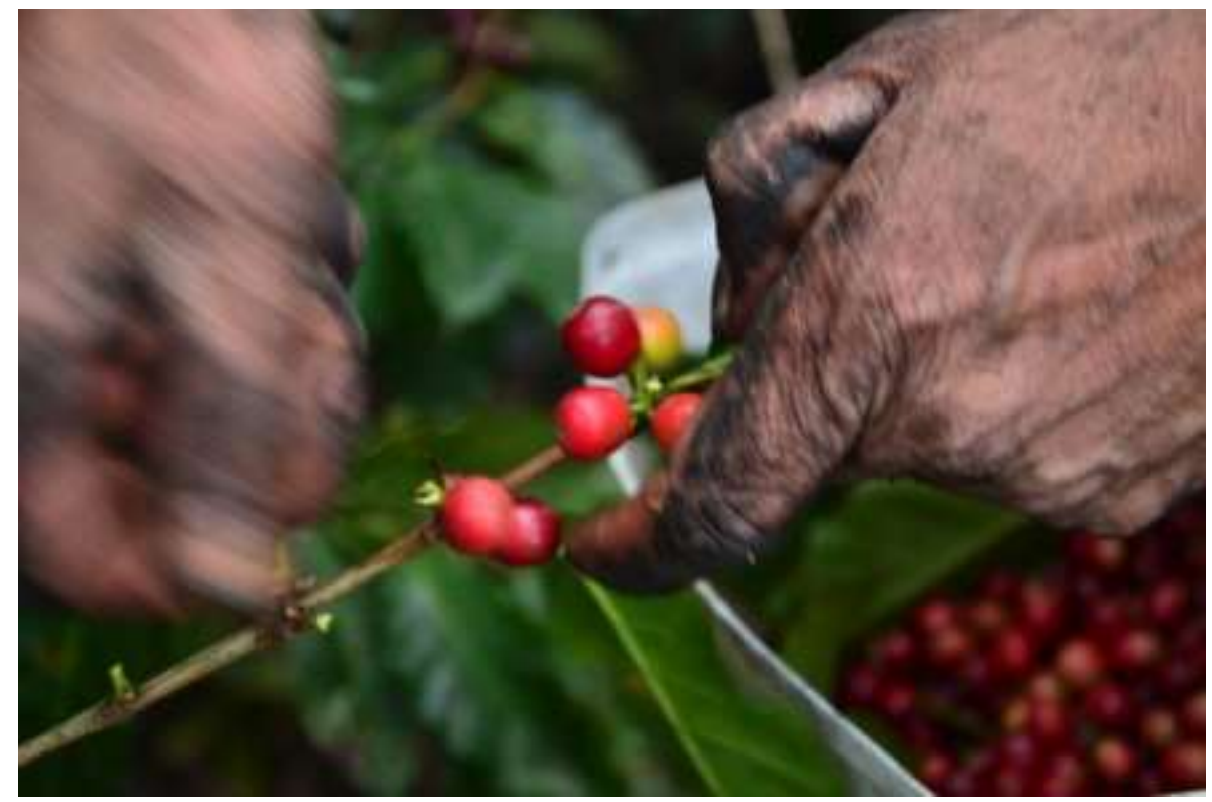




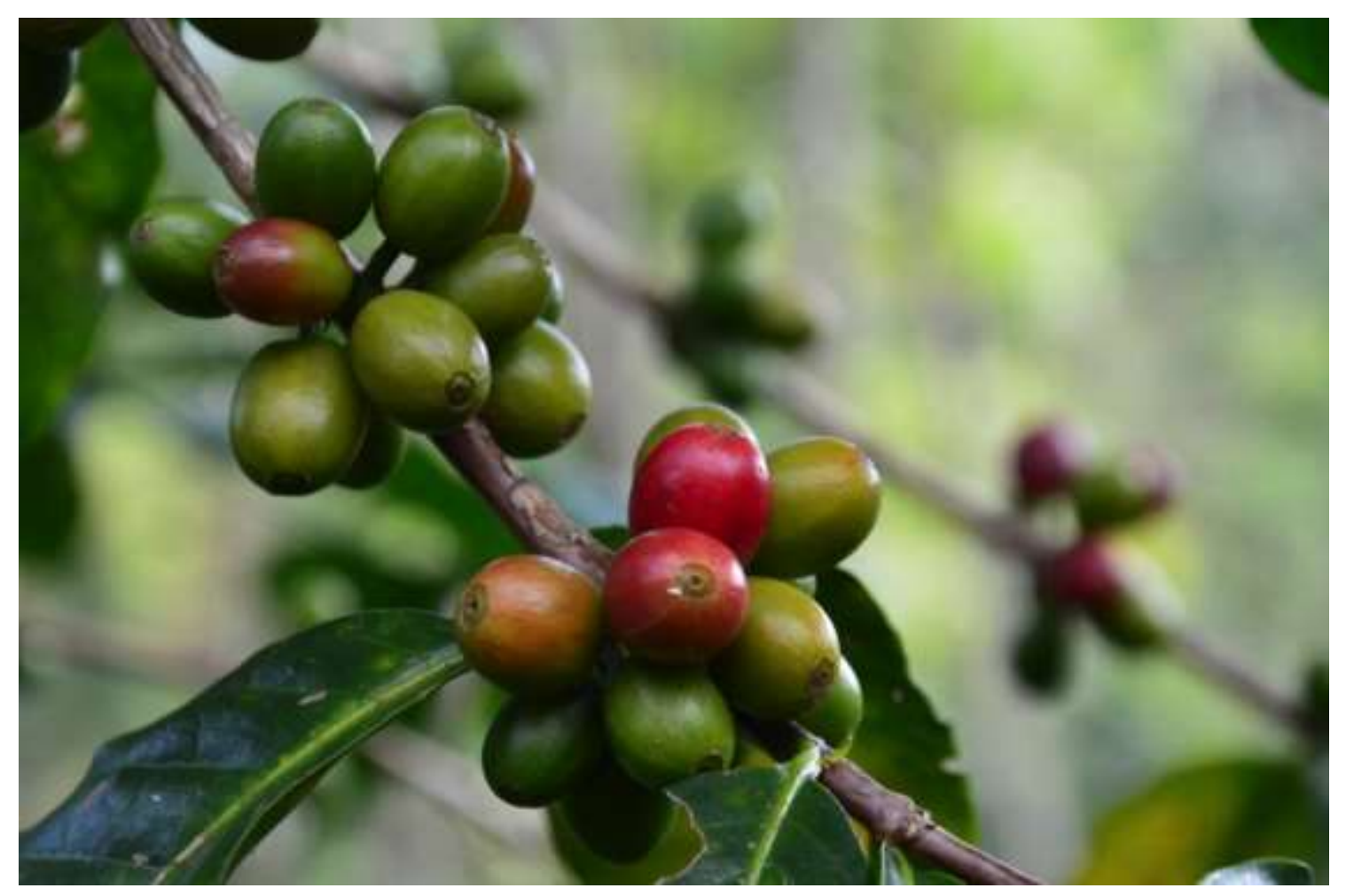

Soy un granito, coloradito, soy muy bonito, soy el café, soy la delicia de quien me toma, quien me cultiva rico lo haré.

Hay en el campo mil verdes hojas, mil largas ramas,

perfumo el aire de sus amores, porque yo tengo bonitas flores. Es la cosecha un gran sustento, doy a los pobres un gran sustento y aunque trabajo todito el día pero me toman con alegría.

A sus 80 años, don Lorenzo es productor de café y versador de Vaquería, municipio de Cosautlán, San Marcos, Veracruz. Junio de 2011. 
El método cualitativo revela significados que sustentan acciones sociales bajo el estudio directo de grupos y personas en un periodo de tiempo, donde el investigador trabaja y convive con un grupo, organización o comunidad, observando y preguntándose por lo que piensan y hacen los actores sociales, cómo construyen sus estrategias de sobrevivencia y cómo reproducen sus prácticas culturales.

Hay dos formas en que trabajamos la interacción entre los investigados e investigadores: primero, presentamos en exposiciones fotográficas de gran formato parte del material obtenido en las comunidades o sitios dedicados a ello en las cabeceras municipales; segundo, realizamos talleres para recuperar la historia de la comunidad a través de la oralidad. Uno de los resultados es el asombro, ante lo cual se preguntan las similitudes entre ellos y quienes aparecen en las fotografías o ante una historia de la comunidad que no conocían ni imaginaban.

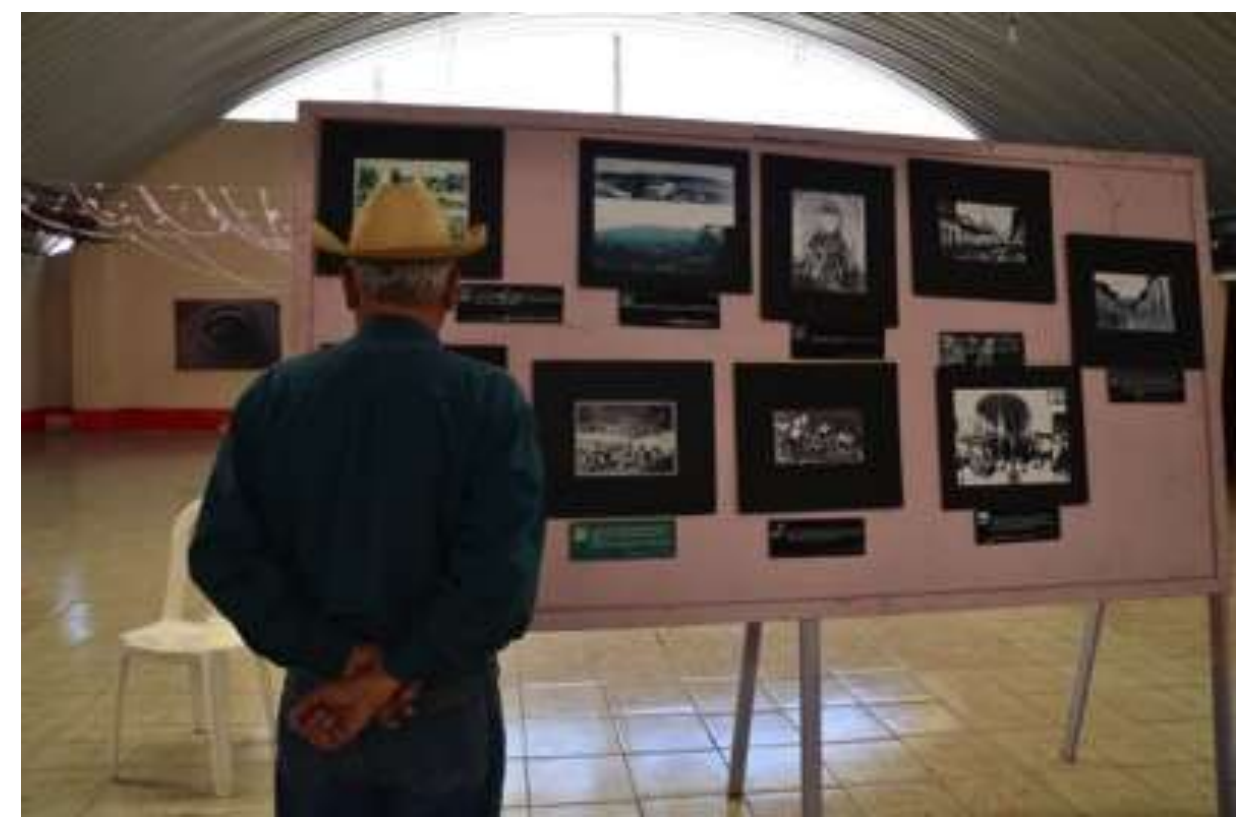

TAller en TOtutla, Veracruz Junio de 2012

Este proyecto se caracterizó por la interdisciplinariedad. En su presentación a las comunidades se exhibía una exposición de la cafeticultura del siglo XIX. El recuerdo, lo que permanece, lo que sigue vigente y las comparaciones fueron puntos decisivos para que la mayoría de los visitantes leyera cuidadosamente la información de cada fotografía. 


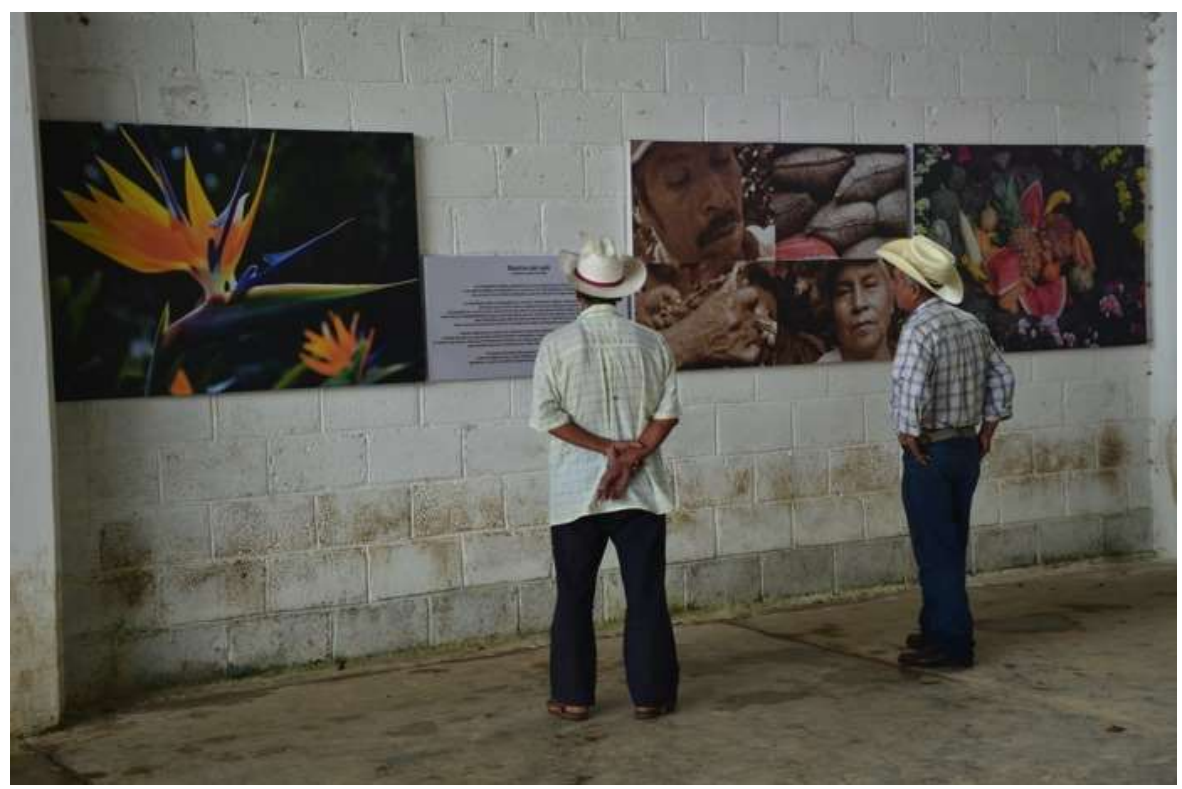

Taller en Napoala, municipio de Atzalan, Veracruz Agosto de 2012

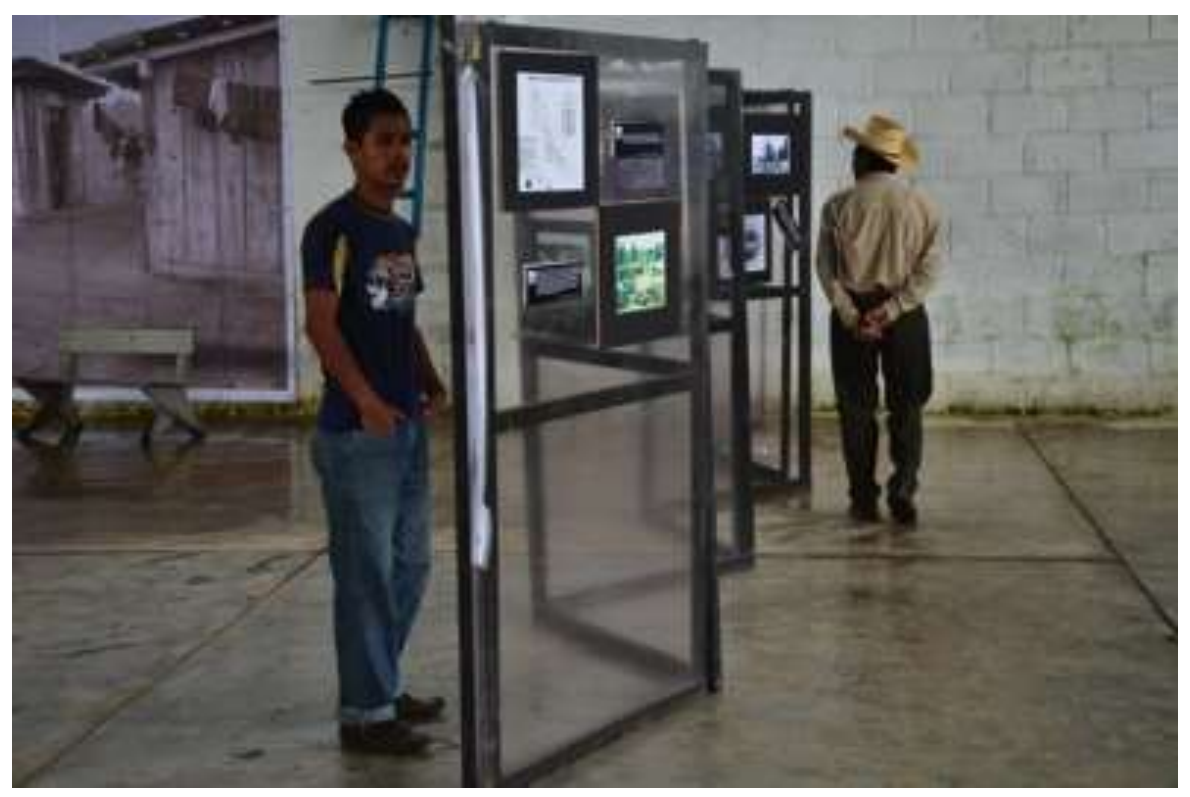

Así como el pasado se exhibe en cada fotografía, quienes visitan la exhibición son los hacedores del futuro en una necesaria reflexión sobre el presente. Juventud y vejez se replantean su identidad. 
De igual forma, los visitantes se identificaron con la exposición conforme a su vida actual, pues en cada taller se presentaron imágenes de las visitas realizadas en otras subregiones de la Faja de Oro.

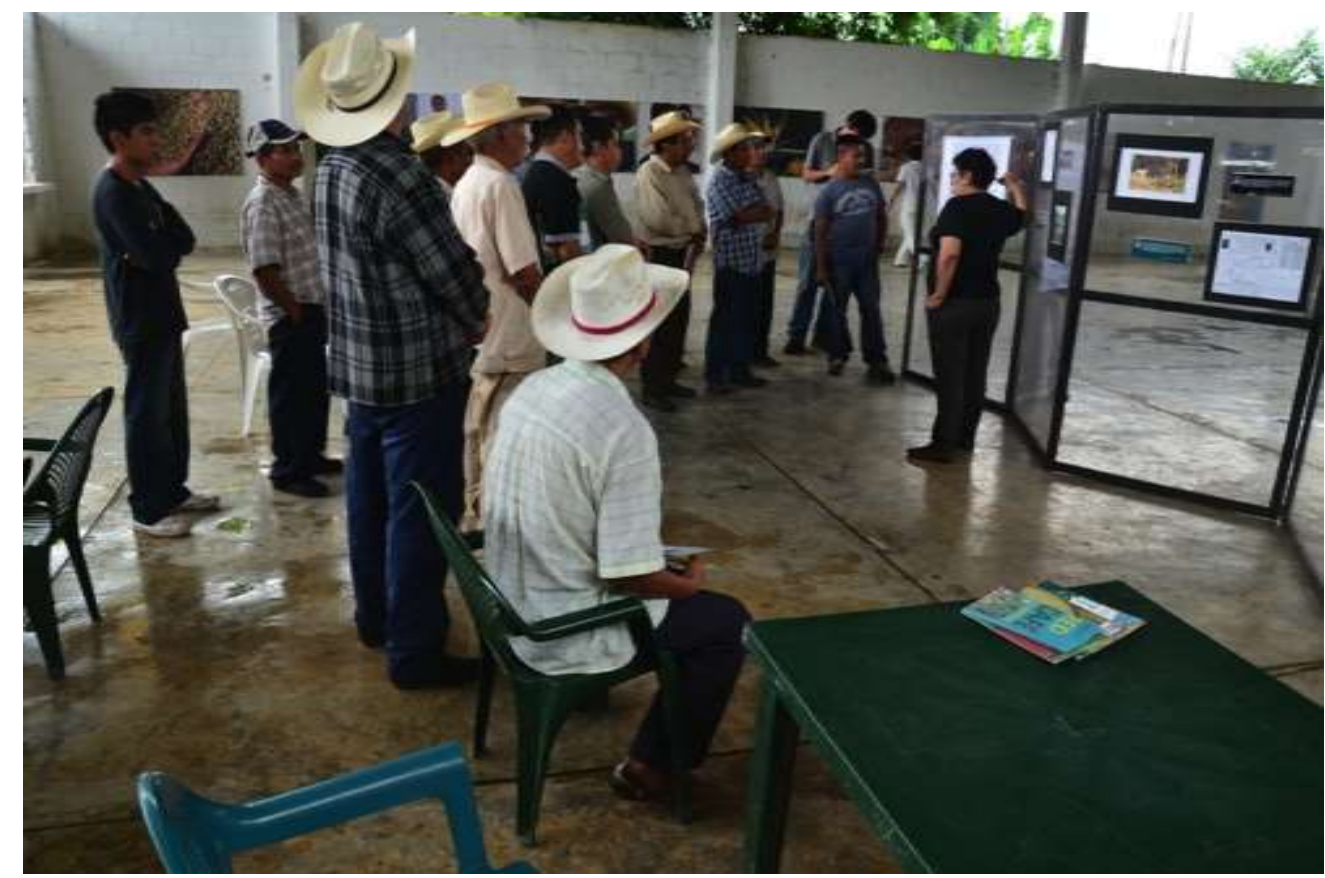

Taller de Napoala, Veracruz

Agosto de 2012

La cultura cafetalera también se construyó a partir de la organización institucional que el Estado mexicano ejerció en aras de elevar la producción. Los productores, acostumbrados a responder a una convocatoria para cafetaleros, únicamente asisten a los talleres si formalmente tiene la propiedad de la parcela. Mujeres, niños y jóvenes que siempre han estado ahí tienen el reto de que esto cambie.

En los talleres, los asistentes escuchan atentos la historia de su cultivo, una historia que, según nos decían, en ocasiones ni siquiera imaginaban. Y la pregunta que surge de inmediato es ¿cómo fue la historia aquí, con nosotros?

En la imagen precedente, observamos tres generaciones. A la expectativa está el más joven, tan atento como todos los cafetaleros presentes. 


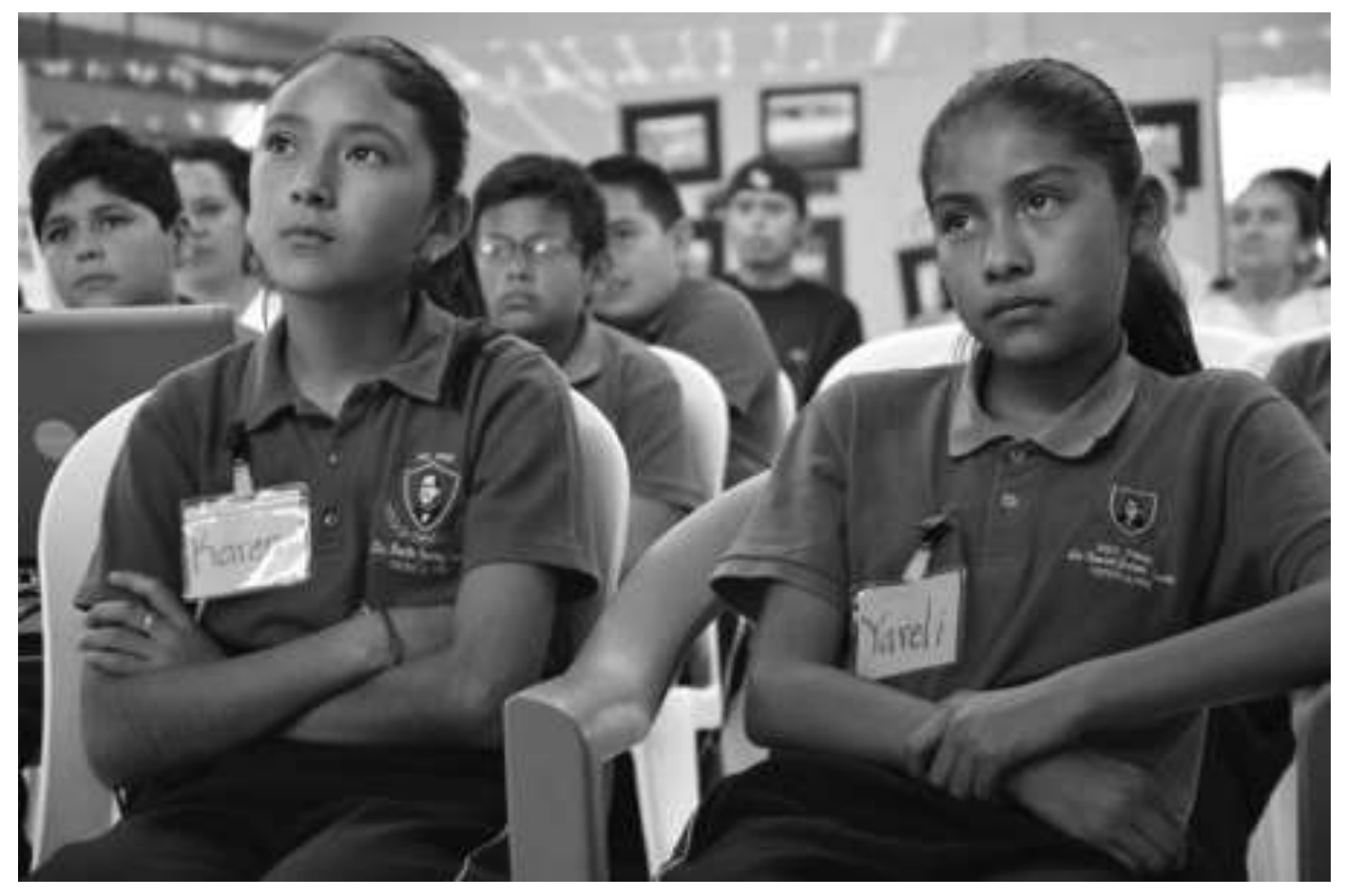

TAller en TOtutla, Veracruz

Junio de 2012

La mujer cafetalera tiene actualmente las opciones que la modernidad ofrece: estudiar, aprender y trabajar.

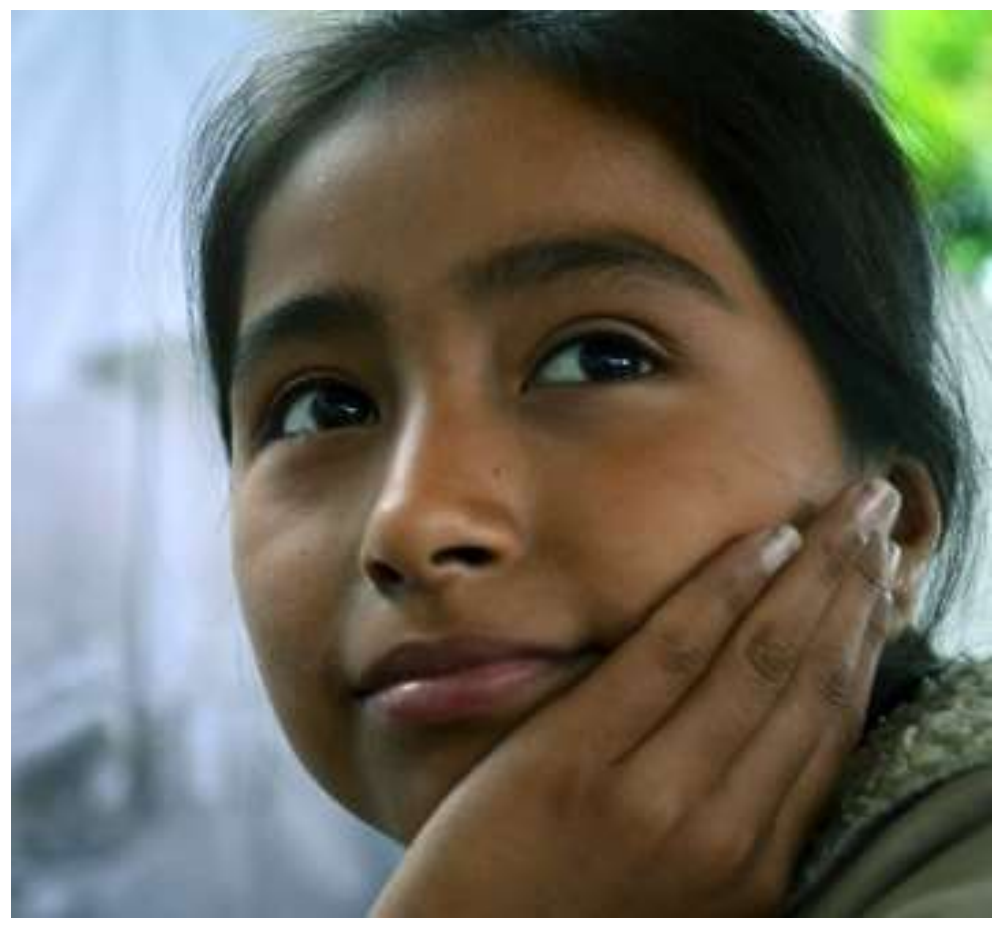




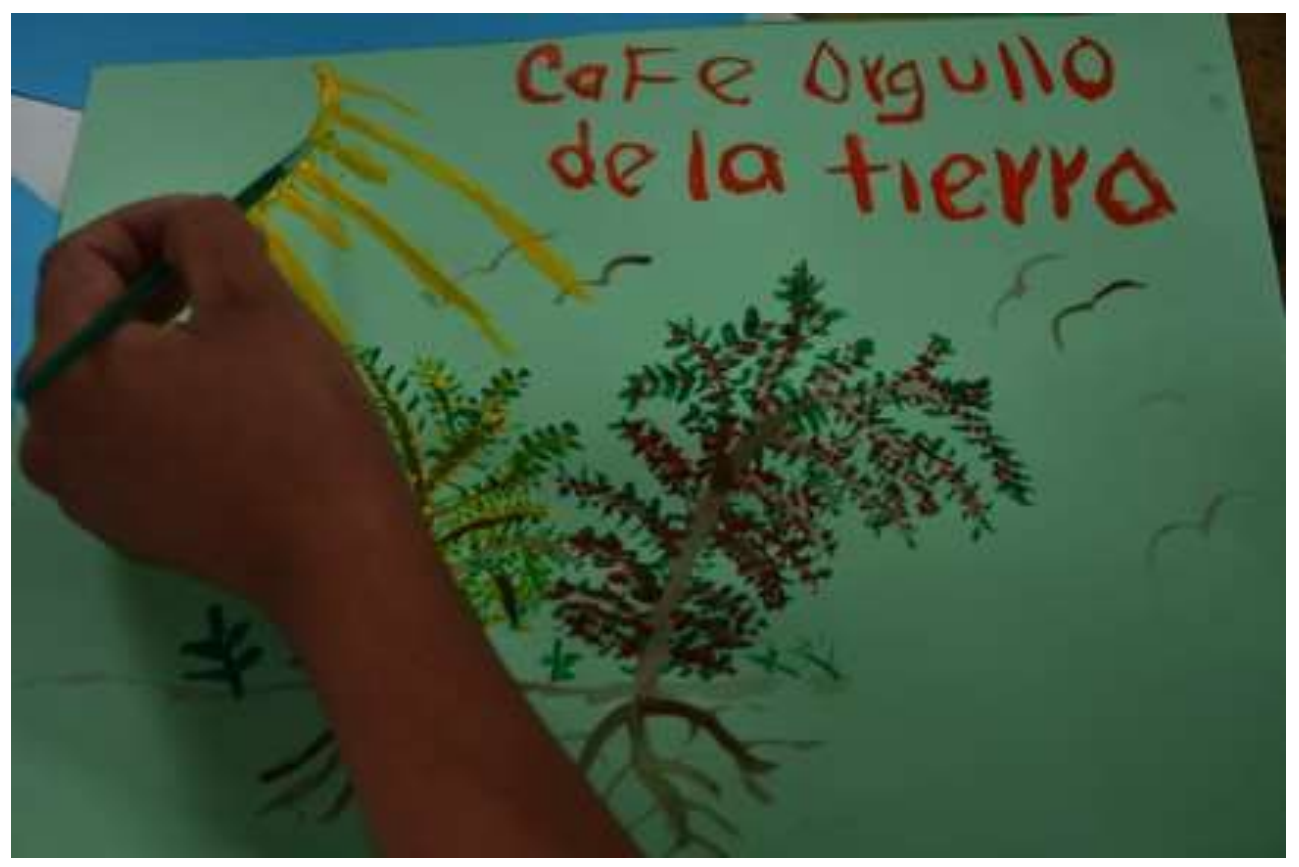

Niña en el Taller en Napoala, municipio de Atzalan, Veracruz

Agosto de 2012

\section{CONCLUSIONES}

Las ciencias sociales atraviesan por una redefinición de sus paradigmas a causa del desafío que arroja la crisis estructural del capitalismo. Se habla de la necesidad de apuntalar unas ciencias sociales que respondan a los fenómenos y problemáticas actuales, imaginar el futuro para construir el presente. En esa redefinición los medios audiovisuales juegan un papel importante. En el mundo de las imágenes, la cámara fotográfica y de video podrían revitalizar unas ciencias sociales críticas y creativas.

Hoy en día los cafeticultores veracruzanos reconocen la necesidad e importancia de transitar hacia una cafeticultura sustentable capaz de enfrentar los problemas del cambio climático, que ha traído un aumento en la incidencia de plagas y enfermedades. Esto significa, en primer lugar, la renovación de plantaciones, viveros modernos y prácticas de reacctivación del suelo — como efecto de la llamada Revolución Verde, el exceso de uso de fertilizantes y plaguicidas deterioró el sustrato de suelo que retenía la materia orgánica-, así como la reforestación con especies nativas.

Por otra parte, el mercado internacional ha decidido girar hacia la calidad del aromático; para muchos productores aún no es clara esta tendencia ni logran apropiarse de ella. Persisten en trabajar para aumentar la productividad de su finca, siendo éste 
uno de los grandes retos del presente siglo. Por ello, con su presencia ante la cámara, los cafeticultores nos transmiten a sus dudas, expectativas y dilemas.

La expresión de identidades pasadas y un recuento de las que están vigentes hace que esta población: mujeres, jóvenes y niños, ante la herencia impostergable de continuar con la cafeticultura, se planteé la importancia de conocer su pasado y el qué hacer en el presente. A partir de este encuentro entre "los cafetaleros" y "sus hijos y esposas", se discute y valora la importancia de heredar la tierra, de mantener costumbres, de intentar hacer agricultura sustentable.

\section{REFERENCIAS}

Bartra, A. (septiembre-octubre, 2000). Las poses de López. Cuartoscuro. VII(44).

Berger, J. (2000). Modos de ver. Barcelona: Gustavo Gilli.

Bourdieu, P. (1977). La fotografía un arte intermedio. Barcelona: Anagrama.

Córdova S. S. (2005). Café y sociedad en Huatusco, Veracruz. Formación de la cultura cafetalera (1870 - 1930). Prólogo de Eugenia Meyer. México: CONACultaUACH (Colección Regiones).

Córdova S. S. (2009). Constructores de la cultura cafetalera del siglo XX. Finqueros y ejidatarios, dos sectores antagónicos. En: Espinoza O. A., Cervantes E.F., Espinosa A. E. (Eds.), Balance y perspectivas del campo mexicano: a más de una década del TLCAN y del movimiento zapatista. Tomo II. Globalización y respuestas locales de la agroindustria (pp. 53-79). México: AMER, Juan Pablos Editor, UAEM, CONACYT.

Eccardi, F., y Sandalj, V. (2000). Il Caffe. Territori e diversità. Trieste, Italy: Trading Company.

Díaz, G. (2009). Apuntes para una sociología de la imagen, (investigación social y fotografía).

En: Garrido, C. (Coord.), Huellas de la migración (pp. 53-66). Xalapa: IIHS, UV (Cuadernos de Trabajo).

López, N. (1996). Mi punto de partida. En: N. López (Coord.), Antología de fetiches. Xalapa: IVEC.

Sontag, S. (1979). Sobre la fotografía. Madrid: Eldhasa. 